\title{
Erratum
}

\section{Presence in the stroma of chloroplasts of a large pool of a ribosomal protein not structurally related to any Escherichia coli ribosomal protein}

\section{Dao-Xiu Zhou and Régis Mache}

Laboratoire de Biologie Moléculaire Végétale, CNRS (URA 1178) and Université Joseph Fourier, B.P. 53X, F-38041 Grenoble, France

Mol Gen Genet (1989) 219:204-208

The DNA sequence given in Fig. 3 is missing a T at position 616. The corrected translated sequence is the following:

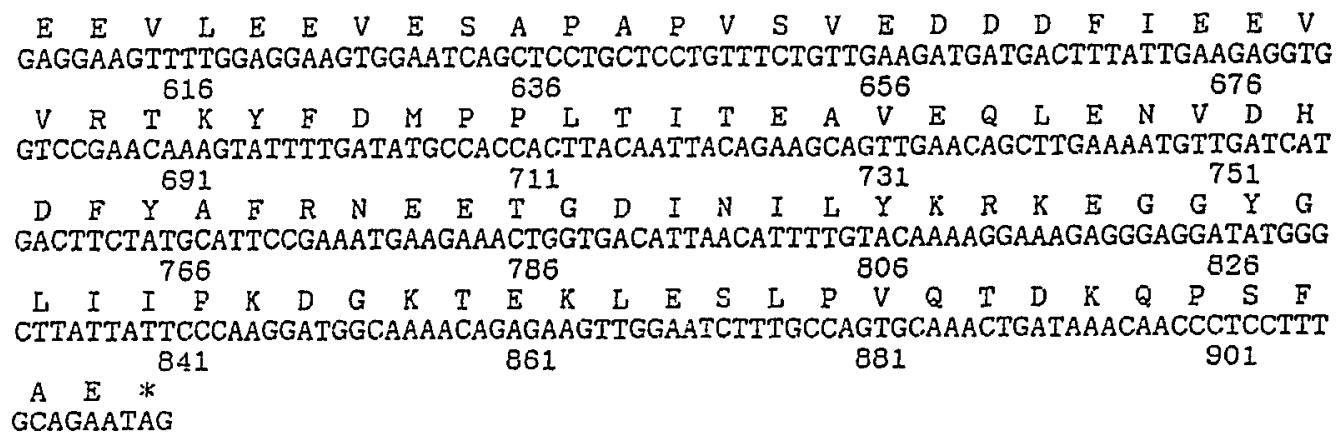

Therefore the total protein is shortened by 19 amino acids. The full length protein deduced from the corrected cDNA has an apparent molecular weight of $35 \mathrm{kDa}$ and the mature protein of $27 \mathrm{kDa}$. 